Original Research Article

\title{
Comparative analysis of cutaneous drug reactions among different fluoroquinolones: an experimental study
}

\author{
Susandhya Devadarshini, Kali Prasad Pattnaik*, Rajashree Samal, Jigyansa Mohapatra, \\ Swayam Sourav Sahoo
}

Department of Pharmacology, SCB Medical College, Cuttack, Odisha, India

Received: 18 April 2017

Accepted: 24 April 2017

*Correspondence to:

Dr. Kali Prasad Pattnaik,

Email:

drkaliprasad@yahoo.co.in

Copyright: (C) the author(s), publisher and licensee Medip Academy. This is an openaccess article distributed under the terms of the Creative Commons Attribution NonCommercial License, which permits unrestricted noncommercial use, distribution, and reproduction in any medium, provided the original work is properly cited.

\begin{abstract}
Background: Fluoroquinolones are generally well tolerated; most adverse effects are mild and common are GI upset. But recent literatures suggest increase reports of Cutaneous Drug reactions (CDRs) including SJS with Fluoroquinolones. However there is insufficient data both in animal and clinical study regarding comparative Analysis of CDRs among different Fluoroquinolones. Hence the present study was under taken to evaluate incidence of comparative CDRs among different Fluoroquinolones.

Methods: 96 Albino mice were divided into 16 groups of 6 each. Ciprofloxacin, Ofloxacin, Levofloxacin and Moxifloxacin were administered in Group 1-4, 5$8,9-12$ and $13-16$ at the dose of $50 / 100 / 150 / 200 \mathrm{mg} / \mathrm{kg}$ respectively. The following parameters were observed i.e. Number and \% of mice developed CDRs with type and severity. Duration of exposure till development of CDRs, time to Recovery and Mortality in each group.

Results: Ofloxacin produced maximum number of CDRs i.e. in $33.3 \%$ mice which was significantly higher than that with levofloxacin $\left(\mathrm{p}=0.006^{*}\right)$. The incidence of CDRs with Ciprofloxacin was $16.67 \%$ and Moxifloxacin $16.67 \%$, but no statistically significant difference than Ofloxacin. The onset for CDRs was significantly earlier with Ofloxacin among the Fluoroquinolones $\left(\mathrm{P}=0.013^{*}\right)$. The reactions varied from severe dermatitis to serious exfoliation of the skin with ofloxacin and Ciprofloxacin, Alopecia with Moxifloxacin but no cutaneous reactions to Levofloxacin. Mortality was found only with Ofloxacin $(12.5 \%)$.

Conclusions: CDRs are common and may present as severe skin exfoliation or Alopecia with Fluoroquinolones. The CDRs are Maximum with Ofloxacin without significant difference from ciprofloxacin but significantly higher than levofloxacin which has least potential for CDRs. Fatality may occur with Ofloxacin.
\end{abstract}

Keywords: Cutaneous drug reactions, Fluoroquinolones, Epidermal necrolysis, Mice model

\section{INTRODUCTION}

Cutaneous drug reactions are one of the most common types of adverse reaction to drug therapy, with an overall incidence of 1-5\%. ${ }^{1}$ The Fluoroquinolones as a class are generally well tolerated; most adverse effects are mild in severity, self-limiting and rarely result in treatment discontinuation. ${ }^{2}$ The most commonly occurring effects are GI upset (nausea, vomiting, diarrhoea, constipation and abdominal pain; less than $7 \%$ total). Less common effects may include central nervous system (CNS) events (less than 5\%), blood disorders (approximately 5\%), renal disturbances (approximately 4.5\%), and skin hypersensitivity and photosensitivity effects (approximately 2\%). ${ }^{3}$ Steven Johnson Syndrome associated with administration of Ofloxacin had been reported. ${ }^{4}$ Similar reactions have been documented with ciprofloxacin and levofloxacin (a L-racemic isomer of ofloxacin). ${ }^{5}$ In a systematic review of cutaneous drug reactions on Indian Population Patel et.al. have shown that the major suspect groups were antimicrobials $(45.46 \%)$, NSAIDs $(20.87 \%)$ and antiepileptic $(14.57 \%)$, commonly implicated drugs were sulphonamides $(13.32 \%)$, $\beta$-lactams $(8.96 \%)$, carbamazepine $(6.65 \%)$, 
phenytoin $(6.46 \%)$ and Fluoroquinolones $(5.12 \%) .{ }^{6}$ But recently use of Sulphonamides drugs is reduced and Fluoroquinolones are preferred agents in number of situations i.e. Urinary Tract Infection (UTI), Respiratory Tract Infections (RTI), Gastro Intestinal Tract infections and various Sexually Transmitted Diseases. Different Fluoroquinolones i.e. ciprofloxacin, ofloxacin, Levofloxacin and Moxifloxacin are indicated for the above conditions and also used for prolonged therapy in Pulmonary Koch's. The literature search for relative incidence of cutaneous drug reactions among different Fluoroquinolones did not reveal sufficient information either in animal studies or in clinical studies. So study of comparative incidence of cutaneous drug reactions (CDRs) with different Fluoroquinolones may help in selecting one over the other. Hence initially an animal study was planned to find out the relative incidence of cutaneous drug reactions among different commonly used Fluoroquinolones. Mice is used as animal models for Stevens-Johnson Syndrome/Toxic Epidermal Necrolysis, skin from UVB-exposed C57BL/6J mice showed features resembling human photo damage. ${ }^{7,8}$ Mouse is also used as models for alopecia areata for review of preclinical drug screening. ${ }^{9}$ Taking all these into account we used Mice as the animal model for study of relative incidence of cutaneous drug reactions among different commonly used Fluoroquinolones.

\section{METHODS}

This study was conducted in Department of Pharmacology, SCB Medical College, Cuttack in collaboration with Department of Dermatology, over a period of six months from June 2008 to December 2008. Experimental protocol was approved by the Institutional Animal Ethics Committee.

Design of the study was an open level prospective experimental study.

\section{Study procedure}

\section{Selection of animals}

96 albino mice of either sex weighing between 25-35 gm were selected. They were randomly divided in to sixteen groups of 6 mice in each group. All the mice were provided free access to food and water and maintained under standard laboratory conditions.

\section{Selection of drugs}

Four Fluoroquinolones which are available in I.V formulations i.e. Ciprofloxacin - $500 \mathrm{mg} / 100 \mathrm{ml}$, Ofloxacin - $200 \mathrm{mg} / 100 \mathrm{ml}$, Levofloxacin - $500 \mathrm{mg} / 100 \mathrm{ml}$ and Moxifloxacin - $400 \mathrm{mg} / 100 \mathrm{ml}$ were selected for the study.

\section{Administration of the drugs}

Ciprofloxacin was administered in Group 1 to 4 , Ofloxacin in Group 5 to 8, Levofloxacin in Group 9 to 12 and Moxifloxacin in Group 13 to 16 mice at the dose of $50,100,150$ and $200 \mathrm{mg} / \mathrm{kg}$ respectively. All the drugs were administered intraperitoneal to the mice daily till cutaneous drug reactions appeared or till the end of 10 days. After CDRs appeared in any mice the drug was discontinued. The mice were kept in separate cages for observation.

Precautions taken to avoid photosensitive and photo toxic effects: The mice were not exposed to direct sun rays and the drugs are given daily in the evening to avoid photo sensitive and photo toxic effects. ${ }^{10}$

The following parameters were observed:

- $\quad$ Number and \% of mice developed (CDRs) in each group

- Mortality in each group

- $\quad$ Type and Severity of CDRs

- Duration of exposure till development of CDRs and Time to Recovery

\section{Statistical analysis}

The incidence (Percentage) of Cutaneous Drug Reactions(CDRs)in the mice, among the different Fluoroquinolones were compared by applying Chi Square Test with Yates Correction. The duration of onset of CDRs among different Fluoroquinolones were compared by ANOVA.

\section{RESULTS}

The details of cutaneous drug reactions with different Fluoroquinolones are depicted in (Table 1) and the summary of the observations is presented in (Table 2). The following observations were made from the study.

\section{Analysis of CDRs}

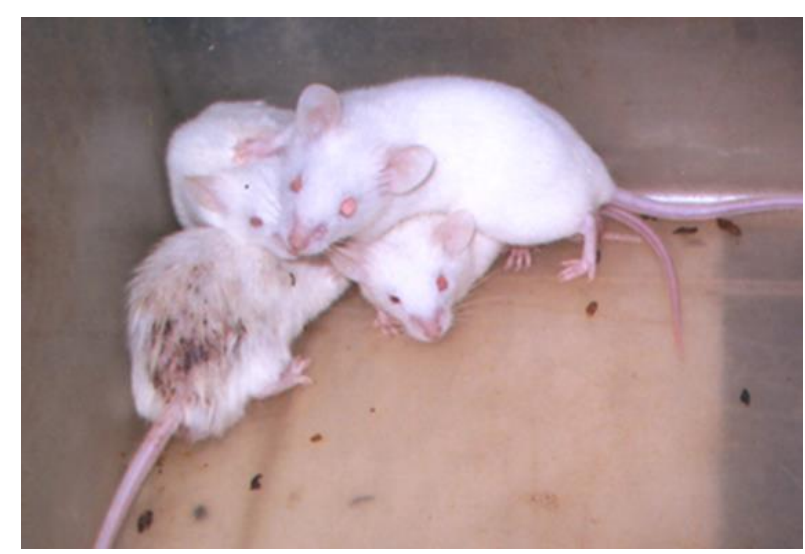

Figure 1: Ciprofloxacin induced skin exfoliation. 
Ciprofloxacin $50 \mathrm{mg} / \mathrm{kg}$ did not produce any CDRs. But serious CDRs including skin exfoliation (resembling Epidermal Necrolysis) developed in $16.67 \%$ (4 out of 24) mice treated with different doses of Ciprofloxacin (Figure
1). The mean duration of exposure before exfoliation was $78 \pm 12$ hours, and no death have occurred in any dose of Ciprofloxacin (Table 1 and 2).

Table 1: Details of Cutaneous Drug reactions (CDRs) with Fluoroquinolones in Mice.

\begin{tabular}{|c|c|c|c|c|c|c|c|}
\hline \multirow{2}{*}{$\begin{array}{l}\text { Groups of } \\
\text { mice, } n=6 \\
\text { (each } \\
\text { group) }\end{array}$} & \multirow[b]{2}{*}{$\begin{array}{l}\text { Name and } \\
\text { dose of the } \\
\text { drugs }\end{array}$} & \multirow{2}{*}{$\begin{array}{l}\text { CDRs } \\
\text { Absent } \\
\text { (number } \\
\text { of Mice) }\end{array}$} & \multicolumn{5}{|c|}{ Cutaneous reactions present } \\
\hline & & & $\begin{array}{l}\text { Number } \\
\text { of mice }\end{array}$ & $\begin{array}{l}\text { Time to } \\
\text { onset in } \\
\text { hours }\end{array}$ & $\begin{array}{l}\text { Type of } \\
\text { reaction }\end{array}$ & $\begin{array}{l}\text { Time to } \\
\text { recovery in } \\
\text { days }\end{array}$ & $\begin{array}{l}\text { Outcome/ } \\
\text { Death time to } \\
\text { death }\end{array}$ \\
\hline Group 01 & $\begin{array}{l}\text { Ciprofloxacin5 } \\
0 \mathrm{mg} / \mathrm{kg}\end{array}$ & 6 & Nil & & & & \\
\hline Group 02 & $\begin{array}{l}\text { Ciprofloxacin } 1 \\
00 \mathrm{mg} / \mathrm{kg}\end{array}$ & 5 & 1 & 96 & Exfoliation & 2days & - \\
\hline Group 03 & $\begin{array}{l}\text { Ciprofloxacin1 } \\
50 \mathrm{mg} / \mathrm{kg}\end{array}$ & 5 & 1 & 72 & Exfoliation & 4days & - \\
\hline \multirow{3}{*}{ Group 04} & Ciprofloxacin & \multirow{2}{*}{4} & 1 & 84 & Exfoliation & 10 days & \\
\hline & $200 \mathrm{mg} / \mathrm{kg}$ & & 1 & 60 & & 10 days & \\
\hline & $\begin{array}{l}\text { Total of } \\
\text { Ciprofloxacin }\end{array}$ & 20 & 4 & $\begin{array}{l}\text { Mean } \pm \text { SD } \\
(84 \pm 9.80)\end{array}$ & & $\begin{array}{l}\text { Mean - } \\
6.5 \text { days }\end{array}$ & No Death \\
\hline Group 05 & $\begin{array}{l}\text { Ofloxacin } \\
50 \mathrm{mg} / \mathrm{kg}\end{array}$ & 5 & 1 & 72 & Dermatitis & 10 days & - \\
\hline \multirow{2}{*}{ Group 06} & \multirow{2}{*}{$\begin{array}{l}\text { Ofloxacin } \\
100 \mathrm{mg} / \mathrm{kg}\end{array}$} & \multirow{2}{*}{4} & \multirow{2}{*}{2} & 48 & Exfoliation & 14 days & \\
\hline & & & & 48 & Exfoliation & 16 days & \\
\hline \multirow[t]{2}{*}{ Group 07} & \multirow{2}{*}{$\begin{array}{l}\text { Ofloxacin } \\
150 \mathrm{mg} / \mathrm{kg}\end{array}$} & \multirow[t]{2}{*}{4} & \multirow[t]{2}{*}{2} & 48 & Exfoliation & Not recovered & $\begin{array}{l}\text { Deathon } 10^{\text {th }} \\
\text { day }\end{array}$ \\
\hline & & & & 48 & Exfoliation & 16days & \\
\hline \multirow{3}{*}{ Group 08} & \multirow{3}{*}{$\begin{array}{l}\text { Ofloxacin } \\
200 \mathrm{mg} / \mathrm{kg}\end{array}$} & \multirow{3}{*}{3} & \multirow{3}{*}{3} & 48 & Exfoliation & Not recovered & $\begin{array}{l}\text { Death on } 7^{\text {th }} \\
\text { day }\end{array}$ \\
\hline & & & & 48 & Exfoliation & Not recovered & $\begin{array}{l}\text { Death on } 5^{\text {th }} \\
\text { day }\end{array}$ \\
\hline & & & & 36 & Exfoliation & 18 days & \\
\hline \multirow{3}{*}{ Group 09-12 } & $\begin{array}{l}\text { Total of } \\
\text { Ofloxacin }\end{array}$ & 16 & 8 & $\begin{array}{l}\text { Mean- } \\
49.5 \pm 10.01\end{array}$ & & Mean-14.8 & $\begin{array}{l}\text { Death of } 3 \\
\text { rats }\end{array}$ \\
\hline & $\begin{array}{l}\text { Levofloxacin- } \\
50 \mathrm{mg} / 100 \mathrm{mg} / \\
150 \mathrm{mg} / \& \\
200 \mathrm{mg} / \mathrm{kg}\end{array}$ & $\begin{array}{l}6+6+6+6 \\
=24\end{array}$ & Nil & 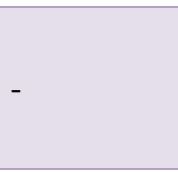 & & - & 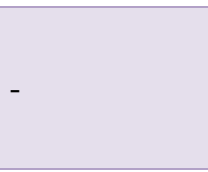 \\
\hline & $\begin{array}{l}\text { Total of } \\
\text { Levofloxacin }\end{array}$ & 24 & Nil & - & & - & No death \\
\hline Group 13 & $\begin{array}{l}\text { Moxifloxacin } \\
50 \mathrm{mg} / \mathrm{kg}\end{array}$ & 6 & Nil & & & & \\
\hline Group 14 & $\begin{array}{l}\text { Moxifloxacin } \\
100 \mathrm{mg} / \mathrm{kg}\end{array}$ & 5 & 1 & 144 & $\begin{array}{l}\text { Stiffening } \\
\text { of hairs }\end{array}$ & Recovered & \\
\hline \multirow[t]{2}{*}{ Group 15} & $\begin{array}{l}\text { Moxifloxacin } \\
150 \mathrm{mg} / \mathrm{kg}\end{array}$ & 4 & 1 & 96 & Alopecia & $\begin{array}{l}\text { No hair growth } \\
\text { weeks }\end{array}$ & fter two \\
\hline & & & 1 & 48 & & & \\
\hline \multirow[t]{2}{*}{ Group 16} & $\begin{array}{l}\text { Moxifloxacin } \\
200 \mathrm{mg} / \mathrm{kg}\end{array}$ & 5 & 1 & 72 & Alopecia & $\begin{array}{l}\text { No hair growth } \\
\text { weeks }\end{array}$ & fter two \\
\hline & $\begin{array}{l}\text { Total of } \\
\text { Moxifloxacin }\end{array}$ & 20 & 4 & $\begin{array}{l}\text { Mean- } \\
90 \pm 40.99\end{array}$ & & No Death & \\
\hline
\end{tabular}

Treatment given injection Pheniramine Maleate (Avil) and injection Dexona

Ofloxacin produced maximum number of CDRs in experimental animals i.e. $33.3 \%$ (8 out of 24 ) mice treated with Ofloxacin developed serious CDRs. The incidence was $6.67 \%$ ( 1 out of 6 mice) in the dose of 
$50 \mathrm{mg} / \mathrm{kg}, 33.3 \%$ (2 out of 6 mice) in the dose of $100 \mathrm{mg} / \mathrm{kg}$ and $150 \mathrm{mg} / \mathrm{kg}$ and $50 \%$ (3 out of 6 mice) with $200 \mathrm{mg} / \mathrm{kg}$ dose. CDRs i.e. Dermatitis and skin exfoliation with Ofloxacin are demonstrated in (Figure 2 and 3).

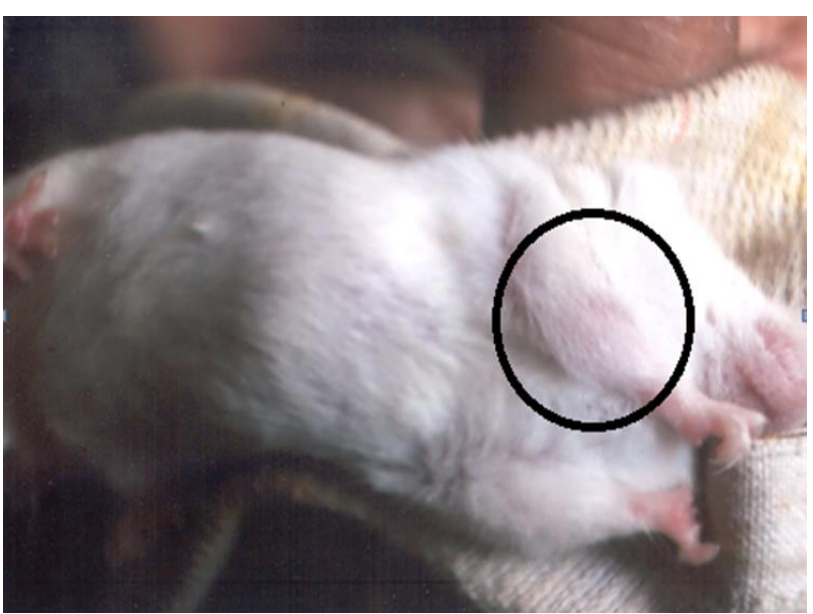

Figure 2: Ofloxacin induced skin rash.

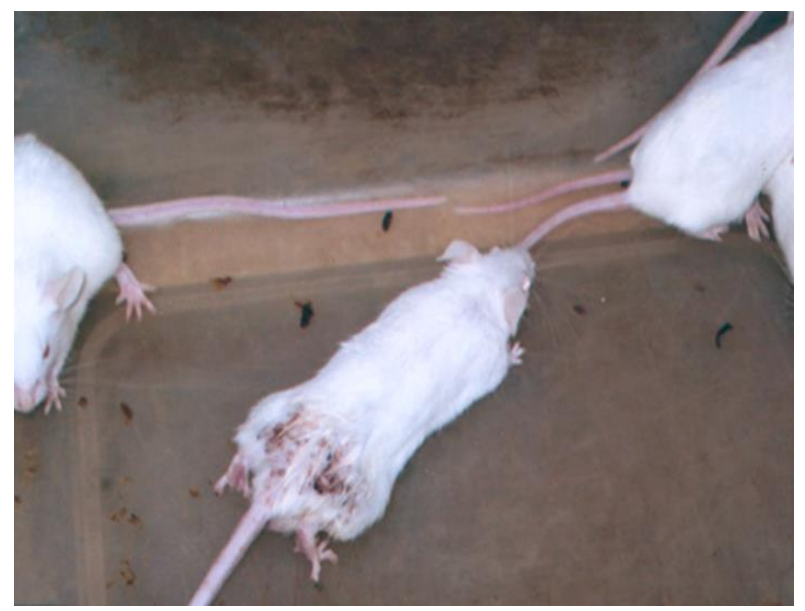

Figure 3: Ofloxacin induced skin exfoliation.

As a whole there was significant difference in the incidence of CDRs among the four Fluoroquinolones $\left(\mathrm{p}=0.048^{*}\right)$. On Individual comparison, Incidence of CDRs with Ofloxacin was significantly higher than levofloxacin $(\mathrm{p}=0.006 *)$. Though the incidence of CDRs with Ofloxacin is higher than that with Ciprofloxacin and Moxifloxacin and the incidence of CDRs with Ciprofloxacin and Moxifloxacin are higher than Levofloxacin but there was no statistically significant difference ( $\mathrm{p}=0.317$ and 0.117 respectively). The mean duration of exposure of Ofloxacin before development of CDRs was $49.5 \pm 10.01$ hours which was significantly earlier among the Fluoroquinolones $(\mathrm{P}=0.013)$ (Table 1 and 2).

Levofloxacin administration in the dose range of $50 \mathrm{mg} / \mathrm{kg}$ to $200 \mathrm{mg} / \mathrm{kg}$ over duration of 10 days did not produce any CDR in any of the 24 mice (Table 1 and 2).
Moxifloxacin $50 \mathrm{mg} / \mathrm{kg}$ did not produce any CDRs. $16.6 \%$ mice in dose of $100 \mathrm{mg} / \mathrm{kg}$ developed stiffening of hairs (Figure 4$)$ and $3(25 \%)$ of total 12 mice receiving Moxifloxacin 150 and $200 \mathrm{mg} / \mathrm{kg}$ developed patchy alopecia (Figure 5). None of the mice developed skin exfoliation. The Mean duration of exposure before development of CDRs was $90 \pm 40.99$ hours. No death had occurred in mice treated with Moxifloxacin (Table 1 and 2).

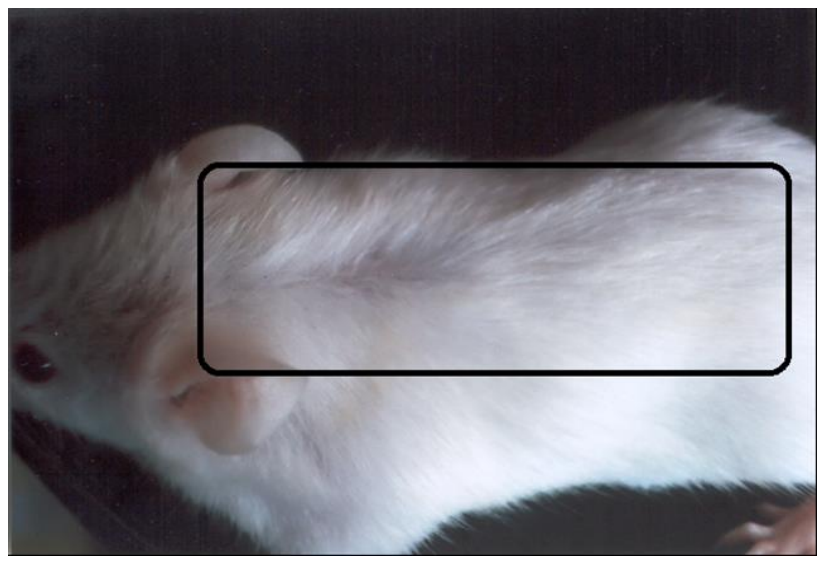

Figure 4: Moxifloxacin induced stiffening of hair.

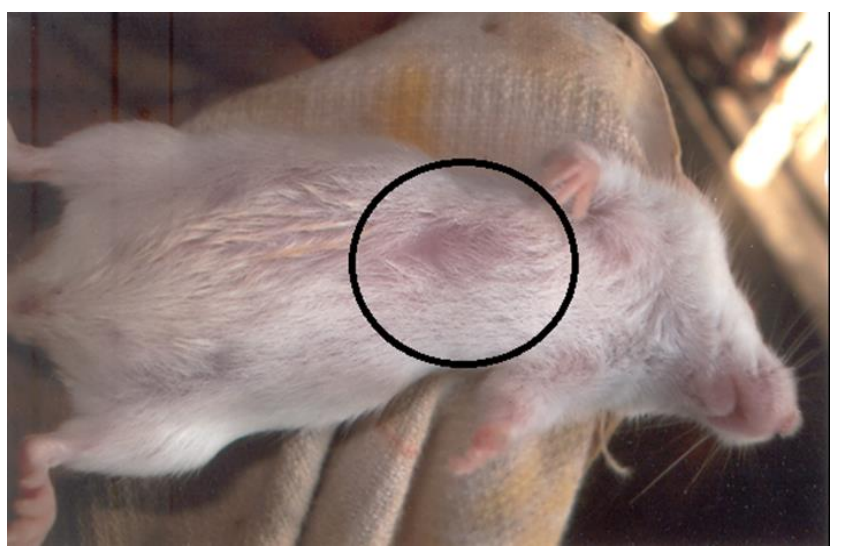

Figure 5: Moxifloxacin induced patchy alopecia.

Comparison of incidence of CDRs by chi square Test with Yates correction:

- Among the 4 Fluoroquinolones by $\chi^{2}$ analysis: $\chi^{2}=$ 9.6, $\mathrm{p}=0.02$, Yates $=7.5$, corrected $-\mathrm{p}=0.048^{*}$

- Between Ofloxacin and levofloxacin: $\chi^{2}=9.6$, $\mathrm{p}=0.0019$, (Yates $=7.35)$, corrected $-\mathrm{p}=0.006^{*}$

- Between Ofloxacin and Cipro /moxi floxacin: $\chi^{2}$ $=1.778, \mathrm{p}=0.182$, $($ Yates $=1)$, corrected $-\mathrm{p}=0.317$

- Between Ciprofloxacin and levofloxacin: $\chi^{2}=4.3$, $\mathrm{p}=0.036$, (Yates $=2.4)$, corrected $-\mathrm{p}=0.117$

\section{Comparison of time for onset of CDRs by ANOVA}

The Table 2 and the statistical analysis showed that as a whole there was significant difference in the incidence of CDRs among the four Fluoroquinolones $\left(\mathrm{p}=0.048^{*}\right)$. On 
Individual comparison, Incidence of CDRs with Ofloxacin was significantly higher than levofloxacin $\left(p=0.006^{*}\right)$. Though the incidence of CDRs with Ofloxacin is higher than that with Ciprofloxacin \& Moxifloxacin and the incidence of CDRs with
Ciprofloxacin and Moxifloxacin are higher than Levofloxacin but there was no statistically significant difference. The onset for CDRs was significantly earlier with Ofloxacin among the Fluoroquinolones $\left(\mathrm{P}=0.013^{*}\right)$.

Table 2: Comparative analysis of cutaneous drug reactions among different fluoroquinolones number of mice in each drug $(n=24)$ total number of mice $(n=96)$.

\begin{tabular}{|c|c|c|c|c|c|c|c|}
\hline Name of drugs & $\begin{array}{l}\text { CDRs } \\
\text { appeared } \\
\text { number } \\
\text { of mice }\end{array}$ & $\begin{array}{l}\text { CDRs did } \\
\text { not } \\
\text { appear } \\
\text { number } \\
\text { of mice }\end{array}$ & $\begin{array}{l}\text { \% of mice } \\
\text { developed } \\
\text { CDRs with } \\
\text { each drug } \\
(\mathrm{n}=24)\end{array}$ & $\begin{array}{l}\% \text { of mice } \\
\text { developed } \\
\text { CDRs within } \\
\text { total number of } \\
\text { Mice (n=96) }\end{array}$ & $\begin{array}{l}\text { Time for } \\
\text { onset of } \\
\text { CDRs in } \\
\text { hours } \\
\text { Mean } \pm \text { SD }\end{array}$ & $\begin{array}{l}\text { Mean } \\
\text { time to } \\
\text { recovery } \\
\text { in days }\end{array}$ & $\begin{array}{l}\% \text { of } \\
\text { death }\end{array}$ \\
\hline Ciprofloxacin & 4 & 20 & $16.67 \%$ & $4.16 \%$ & $(84 \pm 9.80)$ & 6.5 & Nil \\
\hline Ofloxacin & 8 & 16 & $33.33 \%$ & $8.33 \%$ & $49.5 \pm 10.01$ & 14.8 & $12.5 \%$ \\
\hline Levofloxacin & 0 & 24 & Nil & Nil & - & - & Nil \\
\hline Moxifloxacin & 4 & 20 & $16.67 \%$ & $4.16 \%$ & $90 \pm 41.96$ & $\begin{array}{l}\text { Alopecia } \\
\text { persisted } \\
\text { even after } \\
\text { 2-weeks }\end{array}$ & Nil \\
\hline
\end{tabular}

\section{Analysis of death}

Ofloxacin produced death in $12.5 \%$ (3 out of 24 ) mice. Ofloxacin was withdrawn immediately after appearance of exfoliation and the mice were treated with adequate anti-histaminic, steroids and antibiotics creams by the veterinary surgeon. Still there was death of the animals with exfoliation. But in contrast there was no death with other three Fluoroquinolones i.e. ciprofloxacin, levofloxacin, moxifloxacin in the dose range of 50$200 \mathrm{mg} / \mathrm{kg}$ (Table 1 and 2).

\section{DISCUSSION}

Fluoroquinolones are commonly used anti-microbial agent, as a class they are generally well tolerated; most adverse effects are mild in severity, self-limiting and rarely result in treatment discontinuation. ${ }^{2}$ The most commonly occurring effects are GI upset (nausea, vomiting, diarrhea, constipation and abdominal pain; less than $7 \%$ of the total). Less common effects may include central nervous system (CNS) events (less than 5\%), blood disorders (approximately 5\%) and skin hypersensitivity and photosensitivity effects (approximately 2\%). ${ }^{3}$ But recently there is a paradigm shift on the statement regarding safety of Fluoroquinolones. The U.S. Food and Drug Administration (FDA) in its safety communication on May12, 2016 approved changes to the labels of Fluoroquinolones antibacterial drugs for systemic use and states that these medicines are associated with disabling and potentially permanent side effects of the tendons, muscles, joints, nerves, and central nervous system that can occur together in the same patient. As a result, they have revised the boxed warning and have determined that
Fluoroquinolones should be reserved for use in patients who have no other treatment options for acute bacterial sinusitis, acute bacterial exacerbation of chronic bronchitis (AECB), and uncomplicated urinary tract infections (UTI) because the risk of these serious side effects generally outweighs the benefits in these patients. For some serious bacterial infections, the benefits of Fluoroquinolones outweigh the risks, and it is appropriate for them to remain available as a therapeutic option. ${ }^{11} \mathrm{At}$ this juncture we have tried to focus on cutaneous drug reactions (CDRs) of Fluoroquinolones. Though there are some large studies on adverse reactions related to Fluoroquinolones, but till date there is lack of comprehensive study focusing on relative incidence of cutaneous adverse drug reactions among different Fluoroquinolones. Hence initially we have taken up this animal study to focus on this issue. The photosensitive and phototoxic reactions to Fluoroquinolones are already highlighted. ${ }^{8}$ So we have conducted our study in mice model without exposing them to direct Ultra-Violet irradiation or direct Sun ray exposure, to study the direct effect of Fluoroquinolones on the skin by minimizing risk of photosensitive and phototoxic reactions. ${ }^{10}$ Again many studies on mice is done on hairless skin to see the effect on epidermis and dermis. But we have used the mice with intact hairs to see the effect both on the hairs and the skin.

In our systematic comparative study, we found that among the commonly used Fluoroquinolones, Ofloxacin produced maximum number of cutaneous drug reactions (CDRs) i.e. in $33.3 \%$ mice which was significantly higher than Incidence of CDRs with levofloxacin $\left(\mathrm{p}=0.006^{*}\right)$. Though the incidence of CDRs with Ofloxacin is higher than that with Ciprofloxacin and Moxifloxacin and the 
incidence of CDRs with Ciprofloxacin and Moxifloxacin are higher than Levofloxacin but there was no statistically significant difference with the present number mice (Table 2). The onset for CDRs was significantly earlier with Ofloxacin among the Fluoroquinolones $\left(\mathrm{P}=0.013^{*}\right)$. The reactions varied from severe dermatitis to serious exfoliation (resembling Epidermal Necrolysis) of the skin with ofloxacin and Ciprofloxacin. There were various grades of Alopecia with Moxifloxacin. There were no cutaneous reactions to Levofloxacin. These reactions are possibly direct cutaneous reactions to Fluoroquinolones rather than photosensitive or phototoxic reactions as we have minimized the risk of these reactions in our study methodology. The onset of these reactions was earliest i.e. $(49.5 \pm 10.01$ hours) with Ofloxacin which was significantly earlier among the Fluoroquinolones (P $\left.=0.013^{*}\right)$.

In a study by K. Owen, in 1998, mice were given different Fluoroquinolones at an oral dose of $200 \mathrm{mg} / \mathrm{kg}$ followed by exposure to $20 \mathrm{j} / \mathrm{cm}^{2}$ long wave UV irradiation and showed that Lomefloxacin and Sparfloxacin caused erythema and oedema which were severe and lasted for 7-10 days, in contrast erythema with Grepafloxacin, Ciprofloxacin and Ofloxacin was relatively mild and short lived. ${ }^{12}$ However in our study Ofloxacin has highest and severe CDRs with earliest onset of reactions followed by Ciprofloxacin. This difference may possibly be due to more direct cutaneous reactions of Ofloxacin and ciprofloxacin than photosensitive reactions. Moxifloxacin induced Alopecia found in our study was not reported earlier.

Though text books comments that most common adverse reactions to Fluoroquinolones involve GI Tract (3-17\%), followed by CNS (0.9-11\%) followed by Musculoskeletal and cutaneous reactions, but in a clinical study on adverse drug reactions related to the use of Fluoroquinolones Antimicrobials in Italy in 2003, the most frequently reported reactions to Fluoroquinolones, involved the skin, but their percentage $(25 \%)$ was significantly lower ( $p$ $<0.01)$ than those of other systemic antimicrobials $(58.5 \%) .{ }^{13}$ They found some significant differences in the safety profiles of individual Fluoroquinolones: ciprofloxacin was more frequently associated with skin reactions ( $\mathrm{p}<0.01$ ), levofloxacin and pefloxacin with musculoskeletal ( $\mathrm{p}<0.01$ ), Stevens-Johnson syndrome were seen only with ciprofloxacin. ${ }^{14}$ In another study in 2011 , it was found that among 166,736 patients who had been treated with Fluoroquinolones, the prevalence of adverse reaction and cutaneous adverse reaction were $0.13 \%$ and $0.09 \%$, respectively. The prevalence of cutaneous reaction to individual Fluoroquinolones varies between $0.04 \%$ and $0.37 \%$. Out of hundred fifty-one subjects with adverse reaction, most of the cutaneous reactions were attributed to ciprofloxacin $(n=93)$, and the most frequent adverse cutaneous reaction seen was maculo papular rash $39.7 \%$. $^{15}$
Justifiably we have focused on Cutaneous Drug Reactions (CDRs) of Fluoroquinolones in this animal study. We have found high incidence of CDRs with Fluoroquinolones i.e. highest (33.3\%) with Ofloxacin followed by $16.67 \%$ with Ciprofloxacin and Moxifloxacin and no CDRs with Levofloxacin. In our study there was $12.5 \%$ mortality in the mice with ofloxacin in dose range of $150-200 \mathrm{mg} / \mathrm{kg}$. No mortality with other three commonly used Fluoroquinolones. Our animal study has pertinent clinical significance. Though various clinical studies mentioned above have shown ciprofloxacin as most common Fluoroquinolone for (CDRs) and some study have commented that StevensJohnson syndrome were seen only with ciprofloxacin, and had no mention about CDRs with Ofloxacin. ${ }^{14}$ our study have shown that among Fluoroquinolones i.e. highest CDRs found with Ofloxacin without significant difference from Ciprofloxacin and Moxifloxacin. ${ }^{14}$ Our recent search in Vigi- Access (the website of Pharmacovigilance of WHO UMC) have shown 6,288 skin reactions with ofloxacin though very high numbers (i.e.30372) of skin reactions also found with Ciprofloxacin. ${ }^{16}$ But it needs to be analyzed whether this difference is due to more use and better spontaneous reporting with ciprofloxacin.

From the present study in mice model we conclude that cutaneous Drug reactions (CDRs) with Fluoroquinolones are common, they may present as severe dermatitis, Skin Exfoliation with Ofloxacin and ciprofloxacin or Alopecia with Moxifloxacin. The incidences of CDRs are Maximum with Ofloxacin without significant difference from ciprofloxacin but significantly higher than levofloxacin which has least potential for CDRs. These CDRs may be direct cutaneous reactions of the drugs rather than Photosensitive and phototoxic reactions.

\section{ACKNOWLEDGMENTS}

Authors would like to acknowledge the Morale support of Pharmacovigilance Programme of India (PvPI), Indian Pharmacopoeia Commission, Ghaziabad for inspiring them to do basic research on adverse drug reactions. Authors are thankful to present Professor and HOD, Pharmacology Dr. Srikanta Mohanty, Professor and HOD, Dermatology Dr. Prasanjeet Mohanty for their inspiration and support and Mr. Bikash Ch. Naik, PG Lab Assistant Pharmacology for assisting the animal experiment during this research.

\section{Funding: No funding sources Conflict of interest: None declared \\ Ethical approval: The study was approved by the Institutional Ethics Committee of SCB Medical College Cuttack}

\section{REFERENCES}

1. Bigby M. Rates of cutaneous reactions to drugs. Arch Dermatol. 2001;137:765-70. 
2. Ball P, Mandell L, Niki Y, Tillotson G. Comparative tolerability of the newer fluoroquinolone antibacterials. Drug Saf. 1999;21:407-21.

3. Childs S. Safety of the fluoroquinolone antibiotics; focus on the molecular structure. Infect Urol. 2000;13:3-10.

4. Naveen KN, Pai VV, Rai V, Athanikar SB. Retrospective analysis of Steven Johnson syndrome and toxic epidermal necrolysis over a period of 5 years from northern Karnataka, India. Indian J Pharmacol. 2013;45(1):80-2.

5. Leone R, Venegoni M, Motola D. Adverse Drug Reactions Related to the Use of Fluoroquinolone Antimicrobials. Drug Safety. 2003;26(2):109.

6. Patel TK, Thakkar SH, Sharma DC. Cutaneous adverse drug reactions in Indian population: A systematic review. Indian Dermatology Online Journal, 2014.

7. Saito N, Yoshioka N, Abe R, Qiao H, Fujita Y, Hoshina D, et al. Stevens- Johnson Syndrome/Toxic Epidermal Necrolysis Mouse Model Generated by Using PBMCs and the Skin of Patients. J Allergy Clin Immunol. 2012;131(2):9.

8. Sharma MR, Werth B, Werth VP. Animal models of acute photodamage: comparisons of anatomic, cellular and molecular responses in C57BL/6J, SKH1 and Balb/c mice. Photochem Photobiol. 2011;87(3):690-8.

9. Sun J, Silva KA, McElwee KJ, King LE, Sundberg JP. The $\mathrm{C} 3 \mathrm{H} / \mathrm{HeJ}$ mouse and DEBR rat models for alopecia areata: review of preclinical drug screening approaches and results; Exp Dermatol. 2008 Oct;17(10):793-805.

10. Snejina G, Vasilev, Mateev G, Lawrence CP. Antimicrobial Photosensitive reactions: Arch Intern Med. 1998;158(18):1993-2000.
11. FDA Drug Safety Communication: FDA updates warnings for oral and injectable fluoroquinolone antibiotics due to disabling side effects, issued on May 12, 2016. Safety Announcement [7-26-2016]. Accessed FDA web site (https://www.fda.gov) on 8.4.2016.

12. Owen K. Comparative Grepafloxacin photo toxicity in mouse skin: Journal of Antimicrobial Chemotherapy. 1998(42):261-4.

13. Petri WA. Sulfonamide3s, TrimethoprimeSulphamethoxazole, Quinolones, and Agents for Urinary Tract Infections, in: Laurence L. Brunton, Brue A. Chabner Editors. Goodman and Gillman's, The Pharmacological Basis of Therapeutics. 25 ${ }^{\text {th }}$ Ed. New York, NY: McGraw-Hill; 2011:1463-1476.

14. Leone R, Venegoni M, Motola D. Adverse Drug Reactions Related to the Use of Fluoroquinolone Antimicrobials An Analysis of Spontaneous Reports and Fluoroquinolone consumption Data from Three Italian Regions: Drug Safety. 2003;26(2):109-20.

15. Kulthanan K, Chularojanamontri L, Manapajon A, Dhana N, Jongjarearnprasert K. Cutaneous adverse reactions to fluoroquinolones Dermatitis. 2011 May;22(3):155-60.

16. Vigi- Access: Global Database of suspected adverse drug reactions (ADRs), maintained by the Uppsala Monitoring Centre. Available from: http://www.vigiaccess.org.

Cite this article as: Devadarshini $S$, Pattnaik KP, Samal R, Mohapatra J, Sahoo SS. Comparative analysis of cutaneous drug reactions among different fluoroquinolones: an experimental study. Int J Basic Clin Pharmacol 2017;6:1254-60. 